\title{
Copper Isotopes and Copper to Zinc Ratio as Possible Biomarkers for Thyroid Cancer
}

\begin{abstract}
Latifa Sarra Kazi Tani ${ }^{1,2 \star}$, Alexandra T. Gourlan ${ }^{2 *}$, Nouria Dennouni-Medjati ${ }^{1}$, Philippe Telouk ${ }^{3}$, Majda Dali-Sahi ${ }^{1}$, Yahia Harek ${ }^{1}$, Qian Sun ${ }^{4}$, Julian Hackler ${ }^{4}$, Moussa Belhadj ${ }^{1}$, Lutz Schomburg ${ }^{4}$ and Laurent Charlet ${ }^{2}$
\end{abstract}

${ }^{1}$ Analytical Chemistry and Electrochemistry Laboratory, University of Abou Bekr Belkaid, Tlemcen, Algeria, ${ }^{2}$ ISTerre: Institut des Sciences de la Terre, Université Grenoble-Alpes, Université de Savoie Mont-Blanc, CNRS, IRD, IFSTTAR, Grenoble, France, ${ }^{3}$ Ecole Normale Superieure de Lyon, Centre National de la Recherche Scientifique, Université Claude Bernard Lyon 1, Lyon, France, ${ }^{4}$ Institute for Experimental Endocrinology, Charité-Universitätsmedizin Berlin, Corporate Member of Freie Universität Berlin, Humboldt-Universität zu Berlin, Berlin Institute of Health, Berlin, Germany

\section{OPEN ACCESS}

Edited by:

Anton Eisenhauer, GEOMAR Helmholtz Center for Ocean

Research Kiel, Germany

Reviewed by:

Alexander Heuser,

GEOMAR Helmholtz Center for Ocean Research Kiel, Germany

Zheniian Zhuo,

Guangzhou Medical University, China

*Correspondence:

Latifa Sarra Kazi Tan

sarra.kazitani@univ-tlemcen.dz Alexandra T. Gourlan alexandra.gourlan@

univ-grenoble-alpes.ft

Specialty section: This article was submitted to

Translational Medicine, a section of the journa

Frontiers in Medicine

Received: 20 April 2021 Accepted: 09 August 2021 Published: 08 September 2021

Citation:

Kazi Tani LS, Gourlan AT, Dennouni-Medjati N, Telouk $P$,

Dali-Sahi M, Harek Y, Sun Q, Hackler J, Belhadj M, Schomburg L and Charlet $L$ (2021) Copper Isotopes and Copper to Zinc Ratio as Possible Biomarkers for Thyroid Cancer.

Front. Med. 8:698167. doi: 10.3389/fmed.2021.698167
Thyroid cancer is the most common endocrine cancer. There is no systematic screening for such cancer, and the current challenge is to find potential biomarkers to facilitate an early diagnosis. Copper $(\mathrm{Cu})$ and zinc $(\mathrm{Zn})$ are essential micronutrients involved in the proper functioning of the thyroid gland, and changes in their concentrations have been observed in the development of cancer. Previous studies have highlighted the potential ${ }^{65} \mathrm{Cu} /{ }^{63} \mathrm{Cu}$ ratio $\left({ }^{65} \mathrm{Cu}\right)$ to be a cancer biomarker. This study tests its sensitivity on plasma samples ( $n=46$ ) of Algerian patients with papillary thyroid carcinoma and a set of corresponding biopsies $(n=11)$. The $\delta^{65} \mathrm{Cu}$ ratio in blood and tumor samples was determined using multi collector inductively coupled plasma-mass spectrometry (MC-ICP-MS), and their corresponding $\mathrm{Cu}$ and $\mathrm{Zn}$ plasma total concentrations using total reflection X-ray fluorescence (TXRF). Plasma concentrations of Cu were significantly higher (1346.1 \pm 328.3 vs. $1060.5 \pm 216.1 \mu \mathrm{g} / \mathrm{L}, p<0.0001)$, and $\mathrm{Zn}$ significantly lower $(942.1 \pm 205.2$ vs. $1027.9 \pm 151.4 \mu \mathrm{g} / \mathrm{L}, p<0.05)$ in thyroid cancer patients as compared to healthy controls $(n=50)$. Accordingly, the $\mathrm{Cu} / \mathrm{Zn}$ ratio was significantly different between patients and controls $(1.5 \pm 0.4$ vs. $1.0 \pm 0.3, p<0.0001)$. Furthermore, the $\delta^{65} \mathrm{Cu}$ plasma levels of patients were significantly lower than healthy controls $(p<0.0001)$, whereas thyroid tumor tissues presented high $\delta^{65} \mathrm{Cu}$ values. These results support the hypothesis that $\mathrm{Cu}$ isotopes and plasma trace elements may serve as suitable biomarkers of thyroid cancer diagnosis.

Keywords: copper, isotopes, zinc, biomarkers, thyroid cancer

\section{INTRODUCTION}

Thyroid cancer is the most frequent malignancy of the endocrine system, responsible for almost $90 \%$ of endocrine cancers $(1,2)$, and accounting for the Surveillance, Epidemiology, and End Results (SEER) Stat Fact $4 \%$ of all new cancer cases in the US (3). Its incidence is increasing with 567.000 new cases annually, ranking it the 9th place worldwide. It is diagnosed three times more in woman $(10.2$ per 100,000) than in men (3.1 per 100,000) (4). In Algeria, thyroid cancer incidence is increasing, taking now the 3rd place in women after breast and colorectal cancer, 
while in 2006 it occupied the 5th position in frequency $(5,6)$. Four types of thyroid cancer are histologically distinguished. The most common is papillary thyroid carcinoma (PTC) representing 80 to $90 \%$ of new thyroid cancer cases (7). There is no systematic detection of thyroid cancer, and the diagnosis is made incidentally in $25 \%$ of cases during the follow-up of another thyroid disease $(2,8)$. Therefore, a current challenge lies in identifying suitable biomarkers for supporting a fast diagnosis of thyroid cancer.

The link between metal trace elements and cancer has not been yet proofed nor much studied, especially in Algeria. Copper $(\mathrm{Cu})$ is an essential metallic trace element for living organisms (9). Changes in $\mathrm{Cu}$ metabolism have been observed concomitantly with the development of cancer (10). However, $\mathrm{Cu}$ is not a carcinogen, but an increased $\mathrm{Cu}$ bioavailability may lead to an increased production of ATP, which is used by cancer cells during proliferation (10). Thus, $\mathrm{Cu}$ contributes to the proliferation of transformed cells by providing the energy required for cell cycle progression (11). As $\mathrm{Cu}$ has a short residence time in the bulk human body ( $<6$ weeks), it is a potential indicator for rapidly evolving diseases such as cancers (12). Like Zinc $(\mathrm{Zn}), \mathrm{Cu}$ is a catalytic cofactor in $\mathrm{Cu} / \mathrm{Zn}$ superoxide dismutase I enzyme (SOD1), and it is the interaction between $\mathrm{Cu}$ and $\mathrm{Zn}$ that allows the enzyme to function properly (13). This enzyme has a very important role in antioxidant defense system of cells, as it converts superoxide into oxygen and hydrogen peroxide. A disturbance of its expression is associated with various cancers such as hepatocellular carcinoma (14), and overexpression of SOD1 promotes tumor growth in lung cancer cells and reduce apoptosis (15). Although significantly elevated concentrations of $\mathrm{Cu}$ and $\mathrm{Cu} / \mathrm{Zn}$ ratio have been observed in the plasma of patients with breast cancer $(16,17)$, it seems that trace metal imbalances $(\mathrm{Cu} / \mathrm{Zn})$ are clinically more sensitive indices of disease than the concentration of any single trace metal alone (13).

Copper naturally has two stable isotopes: ${ }^{63} \mathrm{Cu}(69.2 \%)$ and ${ }^{65} \mathrm{Cu}(30.8 \%)$ (18). The isotopic abundances of copper in human serum can vary according to sex, menopause, and metabolic diseases $(19,20)$. The conventional delta value $\left({ }^{65} \mathrm{Cu}\right)$ is used to report the $\mathrm{Cu}$ isotope abundances and corresponds to the relative deviation of ${ }^{65} \mathrm{Cu} /{ }^{63} \mathrm{Cu}$ ratios in the measured samples from its value in reference material NIST SRM 976. Some studies observed variations in $\delta^{65} \mathrm{Cu}$ and indicated an altered metabolism of cancer cells compared to normal cells $(12,21)$. The differences (corresponding to the isotopic fractionation) are still poorly understood. Several steps such as $\mathrm{Cu}$ reduction, $\mathrm{Cu}$ transport across the membrane or $\mathrm{Cu}$ binding to organic ligands have the potential to generate fractionation and different metabolic processes such as hypoxia and angiogenesis (22). The $a b$ initio calculations can predict quantitively the variation of $\mathrm{Cu}$ isotope abundance, and can provide an overview into a biological process in biological reactions: in tumor, high $\delta^{65} \mathrm{Cu}$ values represent a reserve of the circulating ${ }^{63} \mathrm{Cu}$ isotope, due to absorption by tumor cells, conversely low values indicating an enrichment of the lighter ${ }^{63} \mathrm{Cu}$ isotope in the serum (12, 21). Recent studies on patients with different types of cancer demonstrate that $\mathrm{Cu}$ present in the blood is enriched in light isotopes relative to healthy controls $(12,21,23)$. Consequently, $\mathrm{Cu}$ isotopes have strong potential to constitute meaningful markers of cancer detection. For the moment, this type of studies was only applied for breast, ovarian, and colorectal cancer $(12,21,23)$. In this study, its suitability for thyroid cancer is tested by comparing the abundance of ${ }^{63} \mathrm{Cu}$ and ${ }^{65} \mathrm{Cu}$ in plasma and tissue biopsies of thyroid cancer patients, along with an assessment of total plasma $\mathrm{Cu}$ and $\mathrm{Zn}$ concentrations. Our results support the notion that $\mathrm{Cu}$ isotopes and total trace elements may support early thyroid cancer detection and diagnosis.

\section{MATERIALS AND METHODS}

\section{Blood and Tissues Samples}

The recruitment of patients was done at University Hospital Centers of TLEMCEN and ORAN (Western Algeria) from June 2018 to May 2019. Forty-six patients with PTC and fifty control subjects were randomly and consecutively selected for the study without applying specific exclusion criteria. All participants had been informed of the purpose of this study, their informed consent had been requested and signed in advance, and people refusing to participate were excluded from the study.

The blood samples, before ablation, of the participants were collected using a venipuncture into $4 \mathrm{~mL}$ heparinized tubes and centrifuged at $1,100 \mathrm{x} g$ (relative centrifugal force) for $10 \mathrm{~min}$ using a Sigma $2-16 \mathrm{P}$ centrifuge, the plasma was recovered in aliquots of $500 \mu \mathrm{l}$. A total number of 11 investigated tissues with thyroid cancer were collected after surgery (thyroidectomy). A diagnosis of thyroid cancer disease was confirmed by an independent pathologist after postoperative pathohistological analysis of thyroid tissues. Plasma of the participants and thyroid tissues samples were stored and kept on $-80^{\circ} \mathrm{C}$ freezer until further manipulation.

A questionnaire was filled, via a face-to-face interview, with every participant considering the anthropometric and socio-cultural parameters. Patients presenting other types of malignancies, chronic diseases, or taking a chronic drug therapy were excluded. This study was conducted in accordance with Algerian law (25/2006, resolution No. 387) and approved by the Scientific Ethics Deontology Committee of Tlemcen University.

\section{Copper and Zinc Status Assessment}

Total plasma $\mathrm{Cu}$ and $\mathrm{Zn}$ concentrations were determined by total reflection X-ray fluorescence (TXRF) using a benchtop analyzer (S2 Picofox, Bruker nano GmbH, Berlin, Germany), essentially as described $(24,25)$. All samples were supplemented with a gallium standard for calibration. Aliquots were applied to cleaned and polished quartz glass slides and dried, before being analyzed by X-ray fluorescence. A seronorm serum standard (Sero AS, Billingstad, Norway) served as control and was included in all assay runs. The concentrations determined for total $\mathrm{Cu}$ and $\mathrm{Zn}$ were within the specified range of the standard, and the inter-assay coefficient of variation (CV) was below 15\% during the analysis. 


\section{Copper Isotope Assessment}

Plasma $(200 \mu \mathrm{l})$ and thyroid tumor biopsies $(200 \mu \mathrm{g})$ were mineralized on a hot plate in a mixture of nitric acid and hydrogen peroxide. $\mathrm{Cu}$ was isolated from the other elements using quartz columns following the protocol described in (26, 27). The $\delta{ }^{65} \mathrm{Cu}$ were determined using a Nu Plasma MC-ICP-MS (Nu Instruments, Wrexham, UK) of ENS-Lyon. As MC-ICP-MS suffers from a stable bias, a correction was systematically applied for each isotopic ratio using a constant and known standard of $\mathrm{Zn}$ which was added for each sample and standard. Typical external reproducibility on $\delta{ }^{65} \mathrm{Cu}$ determined from multiple replicates of samples is $\sim 0.05 \%$ for each session. The conventional delta values, $\delta{ }^{65} \mathrm{Cu}$, measured for each sample is defined by the formula below:

$$
\delta^{65} \mathrm{Cu}=\left[\frac{\left({ }^{65} \mathrm{Cu} /{ }^{63} \mathrm{Cu}\right) \text { sample }}{\left({ }^{65} \mathrm{Cu} /{ }^{63} \mathrm{Cu}\right) \text { IStd }}-1\right] \times 10000
$$

Procedural blanks were below $0.06 \mathrm{ng}$ on average and can be neglected regarding the quantities of $\mathrm{Cu}$ isolated.

\section{Statistical Analysis}

Normality of the data was tested using Kolmogorov-Smirnov test. All analysis (Chi-square test, two-samples $t$-test, MannWhitney U, Kruskal-Wallis, Spearman correlation, linear regression, and Receiver Operating Characteristics "ROC") were performed using IBM SPSS Statistic software version 23 (IBM Corporation, USA). The results of continuous variables are provided in mean (95\% K \& Sr peaks CI) and median (IQR) and of categorical variables in percentages (\%). When the $P$-value was $<0.05$ the result was considered as statistically significant, and the degree of the differences are marked as: ${ }^{*} p<0.05,{ }^{* *} p<$ $0.01,{ }^{* * *} p<0.001$, and ${ }^{* * * *} p<0.0001$. All figures were created with GraphPad Prism 9.0.1.

\section{RESULTS}

The study population included 96 individuals, 46 cases with PTC and 50 healthy controls from western Algeria. This population was predominantly female with a ratio of 9:1, which reflects the difference between the sexes in the prevalence of thyroid cancer (28). The average age of the group was $42 \pm 13$ years. The characteristics of the study population are described in Table 1. No significant differences have been observed between cases and controls in the anthropometric parameters. The thyroid parameters were compared with international standards. A value was considered as abnormal when it was outside the standard range: Thyroid Stimulating Hormone (TSH) $0.3<$ $\mathrm{TSH}<5.0 \mu \mathrm{IU} / \mathrm{mL}$, anti-thyroid peroxidase antibodies (TPOab) $<34 \mathrm{UI} / \mathrm{mL}$ and thyroglobulin (TG) levels $3.0<\mathrm{TG}$ $<40 \mathrm{ng} / \mathrm{mL}$. We observed that thyroid biomarkers are highly perturbed in the individuals with thyroid cancer compared to the international standard.

The trace element status of $\mathrm{Cu}$ and $\mathrm{Zn}$ as well as the $\mathrm{Cu} / \mathrm{Zn}$ ratio were compared between PTC patients and healthy controls (Figure 1). Significant higher differences were observed in plasma of $\mathrm{Cu}$ levels and $\mathrm{Cu} / \mathrm{Zn}$ ratio between cases and
TABLE 1 | Characteristics of the study population.

\begin{tabular}{|c|c|c|c|}
\hline Variables & $\begin{array}{c}\text { PTC } \\
\text { patients }\end{array}$ & $\begin{array}{l}\text { Healthy } \\
\text { controls }\end{array}$ & $P$-value \\
\hline Number of participants & 46 & 50 & \\
\hline Number of biopsy tissues & 11 & 0 & \\
\hline Sex (\%) & & & 0.19 \\
\hline Women & $91 \%$ & $85 \%$ & \\
\hline Men & 09\% & $15 \%$ & \\
\hline Age (years) & & & 0.27 \\
\hline Median (IQR) & $39(29,50)$ & $42(36,48)$ & \\
\hline \multirow[t]{2}{*}{ Mean $(95 \% \mathrm{Cl})$} & $40(36,49)$ & $43(39,46)$ & \\
\hline & & & 0.19 \\
\hline >50 years $(\%)$ & $28 \%$ & $20 \%$ & \\
\hline$<50$ years $(\%)$ & $72 \%$ & $80 \%$ & \\
\hline BMI $\left(\mathbf{k g} / \mathbf{m}^{2}\right)$ & & & 0.09 \\
\hline Median (IQR) & $27.8(23.3,32.2)$ & $25.9(23.2,30.5)$ & \\
\hline Mean (95\% Cl) & $28.3(26.6,30.0)$ & $26.4(25.2,27.7)$ & \\
\hline Smoking (\%) & & & 0,27 \\
\hline Yes & $09 \%$ & $14 \%$ & \\
\hline No & $91 \%$ & $86 \%$ & \\
\hline TSH $(\mu I U / m L)$ & & / & \\
\hline Median (IQR) & $92.4(70.9,101.0)$ & & \\
\hline Mean (95\% Cl) & $82.9(75.6,90.0)$ & & \\
\hline TPO-ab (Ul/mL) & & / & \\
\hline Median (IQR) & $16.4(14.7,21.0)$ & & \\
\hline Mean $(95 \% \mathrm{Cl})$ & $38.7(15.5,21.9)$ & & \\
\hline $\mathrm{TG}(\mathrm{ng} / \mathrm{mL})$ & & / & \\
\hline Median (IQR) & $11.9(4.7,87.9)$ & & \\
\hline Mean (95\% Cl) & $109.5(32.8,186.24)$ & & \\
\hline
\end{tabular}

BMI, Body Mass Index; TSH, Thyroid Stimulating Hormone; TPO-ab/ anti-Thyroid Peroxidase antibodies; TG, Thyroglobulin.

controls $(P<0.0001)$. The average Cu levels was $1346.1 \pm 328.3$ $\mu \mathrm{g} / \mathrm{L}$ in PTC patients and $1060.5 \pm 216.1 \mu \mathrm{g} / \mathrm{L}$ in controls. Conversely, significant lower $\mathrm{Zn}$ plasma levels were observed $(P<0.05)$ between the two groups, with average 942.1 \pm $205.2 \mu \mathrm{g} / \mathrm{L}$ and $1027.9 \pm 151.4 \mu \mathrm{g} / \mathrm{L}$ in PTC and healthy subjects, respectively.

We also evaluated, using Spearman's correlation test, the association between trace metals ( $\mathrm{Cu}$ and $\mathrm{Zn}$ ) and thyroid parameters (TSH, TPO-ab, TG). However, no significant associations were observed in PTC patients $(P>0.05)$.

Copper and $\mathrm{Zn}$ concentrations were classified into 3 classes according to international reference values (Table 2). The $\mathrm{Cu}$ value (median $1,060 \mu \mathrm{g} / \mathrm{L}$ ) of our control group was close to the corresponding reference ranges from other countries, such as Germany $(1,020 \mu \mathrm{g} / \mathrm{L}$, with a range of $804-1,620 \mu \mathrm{g} / \mathrm{L})$ (29). In comparison to the healthy controls, more than $16 \%$ of patients with PTC had elevated $\mathrm{Cu}$ concentrations. $\mathrm{Cu}$ levels in the majority of the studied population was within the reference range. In our patients, $\mathrm{Zn}$ concentrations were lower than in our controls, but most of the values were still within the reference range $[785-1,046] \mu \mathrm{g} / \mathrm{L}(28,30)$. However, the distribution of $\mathrm{Cu}$ 

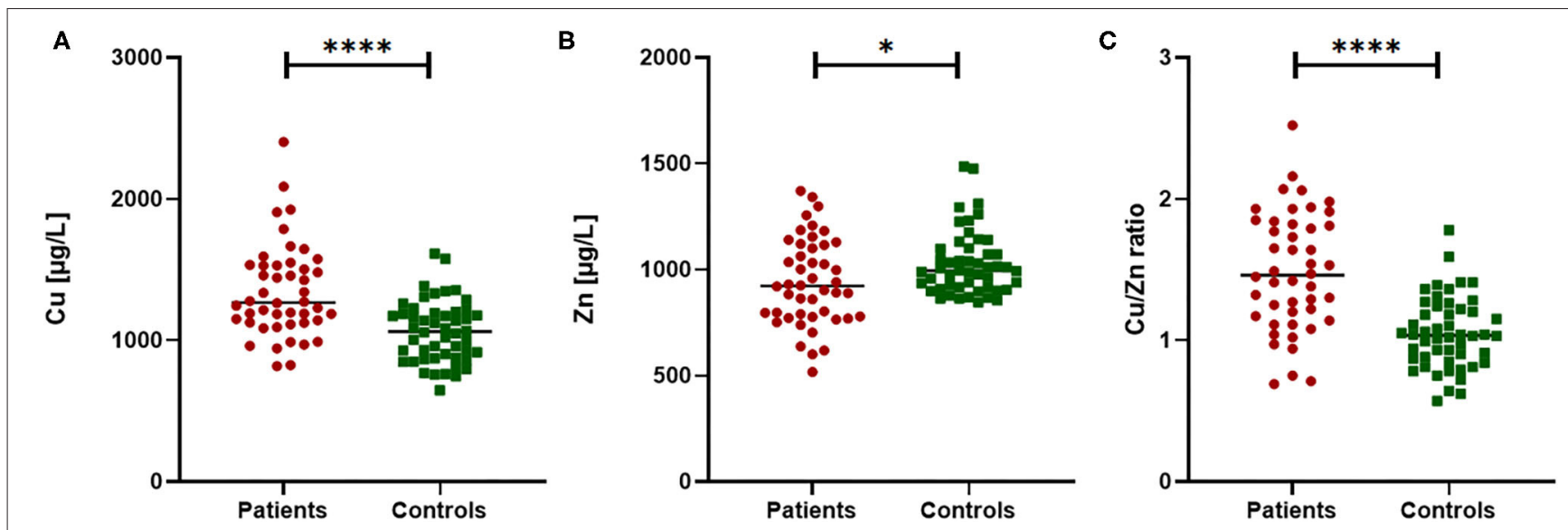

FIGURE 1 | Comparison of Cu, Zn and Cu/Zn ratio in PTC patients vs. healthy controls. Significant differences were observed in plasma Cu concentration (A), Zn concentration (B) and in the Cu/Zn ratio (C). Mann Whitney test for non-normal distribution or $T$-test for variables normally distributed; ${ }^{*} p<0.05$ and ${ }^{* \star * \star} p<0.0001$.

TABLE 2 | Prevalence of elevated Cu and deficient Zn concentrations in PTC patients and healthy controls in comparison to international reference ranges.

\begin{tabular}{lcccc}
\hline Reference values & $\begin{array}{c}\text { PTC } \\
\text { patients (\%) }\end{array}$ & $\begin{array}{c}\text { Healthy } \\
\text { controls (\%) }\end{array}$ & P-value & Reference \\
\hline $\mathbf{C u}[\mu \mathrm{g} / \mathrm{L}]$ & & & 0.0001 & $(29)$ \\
$\mathrm{n} \%(\mathrm{Cu} \leq 804 \mu \mathrm{g} / \mathrm{L})$ & 0 & 86 & \\
$\mathrm{n} \%(804<\mathrm{Cu}<$ & 84 & & \\
$1,620 \mu \mathrm{g} / \mathrm{L})$ & & 0 & \\
$\mathrm{n} \%(\mathrm{Cu} \geq 1,620$ & 16 & & \\
$\mu \mathrm{g} / \mathrm{L})$ & & & \\
$\mathbf{Z n}[\mu \mathrm{g} / \mathrm{L}]$ & & 0 & \\
$\mathrm{n} \%(\mathrm{Zn} \leq 785 \mu \mathrm{g} / \mathrm{L})$ & 26 & 68 & \\
$\mathrm{n} \%(785<\mathrm{Cu}<$ & 46 & & \\
$1,046 \mu \mathrm{g} / \mathrm{L})$ & & 32 & \\
$\mathrm{n} \%(\mathrm{Cu} \geq 1,046$ & 28 & & \\
$\mu \mathrm{g} / \mathrm{L})$ & & & \\
\hline
\end{tabular}

and $\mathrm{Zn}$ concentrations in the classes of the two groups remained significantly different $(P<0.0001)$.

The correlation between $\mathrm{Cu}$ and $\mathrm{Cu} / \mathrm{Zn}$ ratio in the PTC patients (in red, in Figure 2) and in the healthy controls (in green, in Figure 2) was studied. They were widely used as an indicator in breast cancer (12). In the control group, we observed a clear correlation reflecting a strict regulation of $\mathrm{Zn}$ levels in the body $(\mathrm{x} / \mathrm{y}=\mathrm{Zn})$ compared to the cases $(p=0.001)$. The plasma of PTC showed a high degree of deregulation in $\mathrm{Cu}$ and $\mathrm{Zn}$.

We treated each $\delta^{65} \mathrm{Cu}$ plasma measurement for each patient, tissue, and control as an independent measurement (Figure 3). PTC plasma samples had a $\mathrm{Cu}$ isotope ratio ranking from -1.38 to $-0.56 \%$ o (median $-0.86 \%$, mean $-0.90 \pm 0.24 \%$ ) and remained significantly lower $(p<0.0001)$ compared to the healthy controls (between -0.2 and $-0.9 \%$, median $-0.60 \%$, mean $-0.61 \pm 0.21 \%$ ) .

Nevertheless, there was no significant difference between the $\delta^{65} \mathrm{Cu}$ measured in controls and the $\delta^{65} \mathrm{Cu}$ measured in the thyroid tissue biopsies $(p=0.163)$.
We then compared the mean $\delta^{65} \mathrm{Cu}$ of patients and thyroid biopsies and found that there was a significant difference as a mirror effect $(p<0.05)$. We also compared plasma $\delta^{65} \mathrm{Cu}$ values with age, sex and thyroid parameters but no association was found in PTC patients $(p>0.05)$.

Finally, we analyzed $\mathrm{Cu} / \mathrm{Zn}$ ratio and $\delta^{65} \mathrm{Cu}$ data with Receiver Operating Characteristics (ROC) curve analysis (Figure 4). The ROC curve allows us to evaluate the probability that a result obtained is a true positive or a false positive, and the area under the curve (AUC) indicates the probability to get a positive value in front of a negative one. AUC vary between 0.5 (pure chance) and 1.0 (totally reliable). In our case, we evaluated the use of $\mathrm{Cu} / \mathrm{Zn}$ ratio and $\delta{ }^{65} \mathrm{Cu}$ as novel biomarkers in diagnostic tool for thyroid cancer. The results indicate an acceptable degree of accurate diagnosis and prediction, with an $\mathrm{AUC}=0.81$ for $\mathrm{Cu} / \mathrm{Zn}$ axis $(p$ $<0.0001)$ and an $\mathrm{AUC}=0.78$ for $\delta^{65} \mathrm{Cu}$ of axis $(P<0.0001)$, respectively, to discriminate between controls and cancer patients (Figure 4).

\section{DISCUSSION}

In this study, we present a comparison of trace elements in Algerian healthy subjects and patients with a diagnosis of PTC. Our results indicate that both total plasma $\mathrm{Cu}$ and $\mathrm{Zn}$ concentrations with the $\mathrm{Cu} / \mathrm{Zn}$ ratio as well as the $\delta^{65} \mathrm{Cu}$ marker yield fast, low-cost and meaningful insights and may support a thyroid cancer diagnosis. However, the nature of our study is explorative, and a single sample per patient only was available for analysis. For these reasons, the data need to be interpreted with the due caution until the results have been verified in larger study cohorts. Nevertheless, the measurements were conducted by scientists blinded to the clinical phenotypes, and the study groups were of sufficient size to support further research on these novel biomarkers of thyroid cancer. 


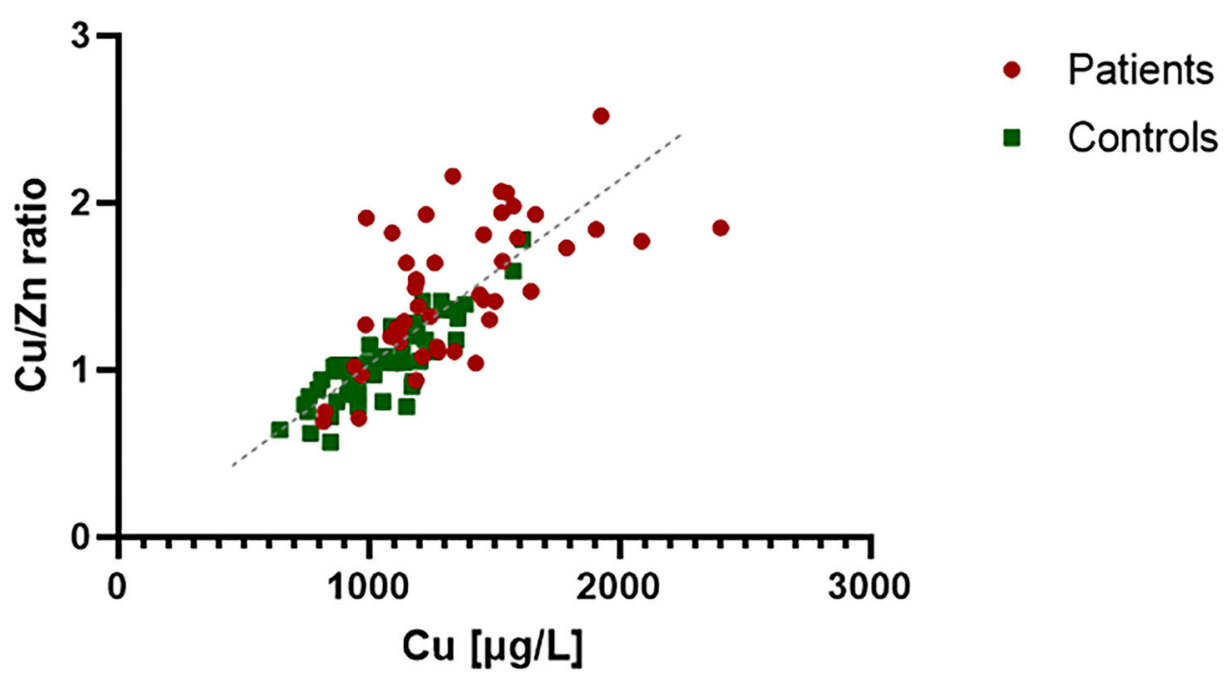

FIGURE 2 | Correlation analysis between $\mathrm{Cu}$ and $\mathrm{Cu} / \mathrm{Zn}$ ratio in plasma of PTC patients and healthy controls. The control group expressed a strong correlation $\left(R^{2}=\right.$ 0.85), which reflect $Z n$ regulation in the body $(x / y=Z n)$. Zn concentration in PTC plasma seems to be less regulated and variable compared to controls $\left(R^{2}=0.39\right)$.

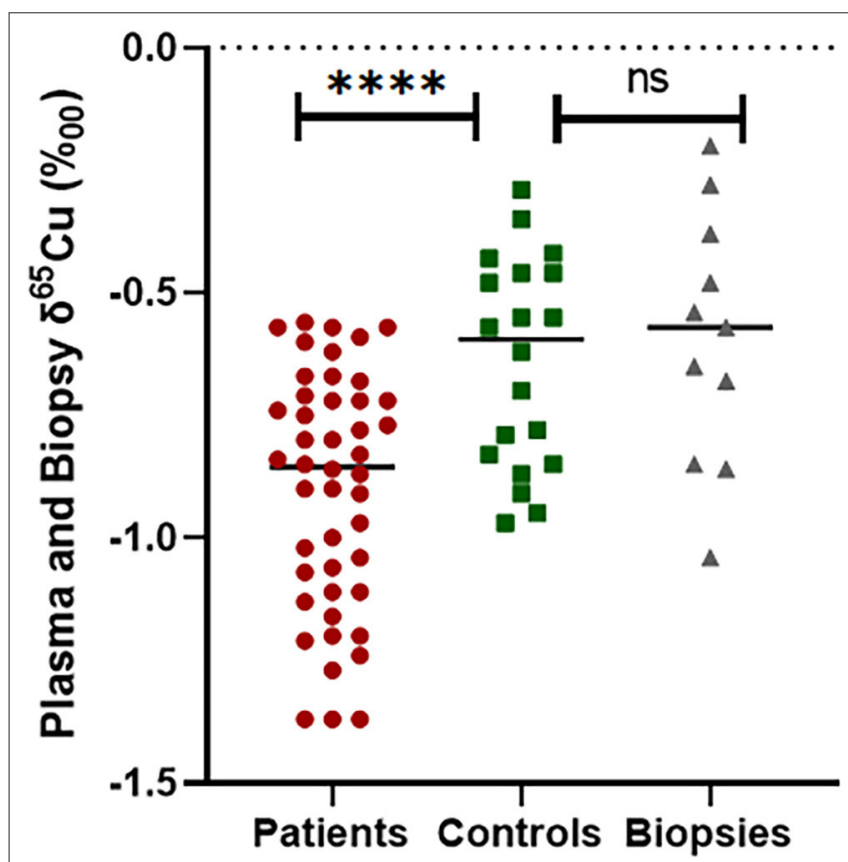

FIGURE 3 | Comparison of $\delta^{65} \mathrm{Cu}$ values between healthy controls plasma and thyroid cancer patients' plasma and biopsy, ${ }^{* \star \star *} p \leq 0.0001$ and ns, no significant differences.

\section{Metals Concentrations and Ratios}

We observed that blood $\mathrm{Cu}$ concentrations were significantly higher and $\mathrm{Zn}$ concentrations significantly lower in thyroid cancer patients compared to healthy controls. $\mathrm{Cu}$ and $\mathrm{Zn}$ are important for thyroid gland function, in metabolism and in synthesis of thyroid hormones (31). Such changes in concentration of trace metal can affect the balance between

oxidant and antioxidant in the body and thus the endocrine system and can result in different thyroid diseases such as hyperthyroidism, hypothyroidism, Hashimoto's disease, and cancer $(31,32)$.

First, Copper interact with tyrosine amino acid metabolism which is necessary for production of thyroid hormones (33). $\mathrm{Cu}$ regulates the excessive absorption of thyroxine (T4) by monitoring the calcium levels and can eliminate free radicals and reduce some damage caused in the cells during the synthesis of thyroid hormones (34). It is reported in some studies, that high levels of $\mathrm{Cu}$ may cause an oxidative stress that can alter normal thyroid function $(31,33,35,36)$. Some studies reported high $\mathrm{Cu}$ blood levels in cancer, and they correlated with grade and therapies response $(10,37)$. Ishida et al. (11) using a mouse model genetically modified of human cervical carcinoma reported a high expression of $\mathrm{Cu}$ transporter $\mathrm{Ctr} 1$ in the cancer cells, and thus tumors might have a higher dependence for $\mathrm{Cu}$. $\mathrm{Cu}$ has the particularity to act as antioxidant and pro-oxidant $(34,38) . \mathrm{Cu}$ is considered as switch activating the angiogenesis process of tumoral cells. Abnormally high concentration of $\mathrm{Cu}$ can facilitate the proliferation of tumors by damaging DNA with toxic free hydroxyl radicals. In addition, high serum $\mathrm{Cu}$ concentrations are correlated with patients having different types of cancer and in most cancers, it is considered as hallmark of cancer cells (39). But for the moment, the effect of $\mathrm{Cu}$ mechanism in angiogenesis is still unclear (10). $\mathrm{Cu}$ is actively involved in the process of tumor progression, particularly during angiogenesis and metastasis (40). Clinical studies in rodent models show that $\mathrm{Cu}$ supplementation significantly increases tumor growth in breast, pancreatic and lung cancer (41). Cu regulates the expression and the secretion of certain angiogenic factors, such as vascular endothelial growth factor (VEGF), fibroblast growth factors (FGF) and interleukin-1alpha (IL-1 $\alpha$ ). Therefore, $\mathrm{Cu}$ indirectly participates in angiogenesis and tumor nutrition (42). 




$\mathrm{Cu} / \mathrm{Zn}$ ratio

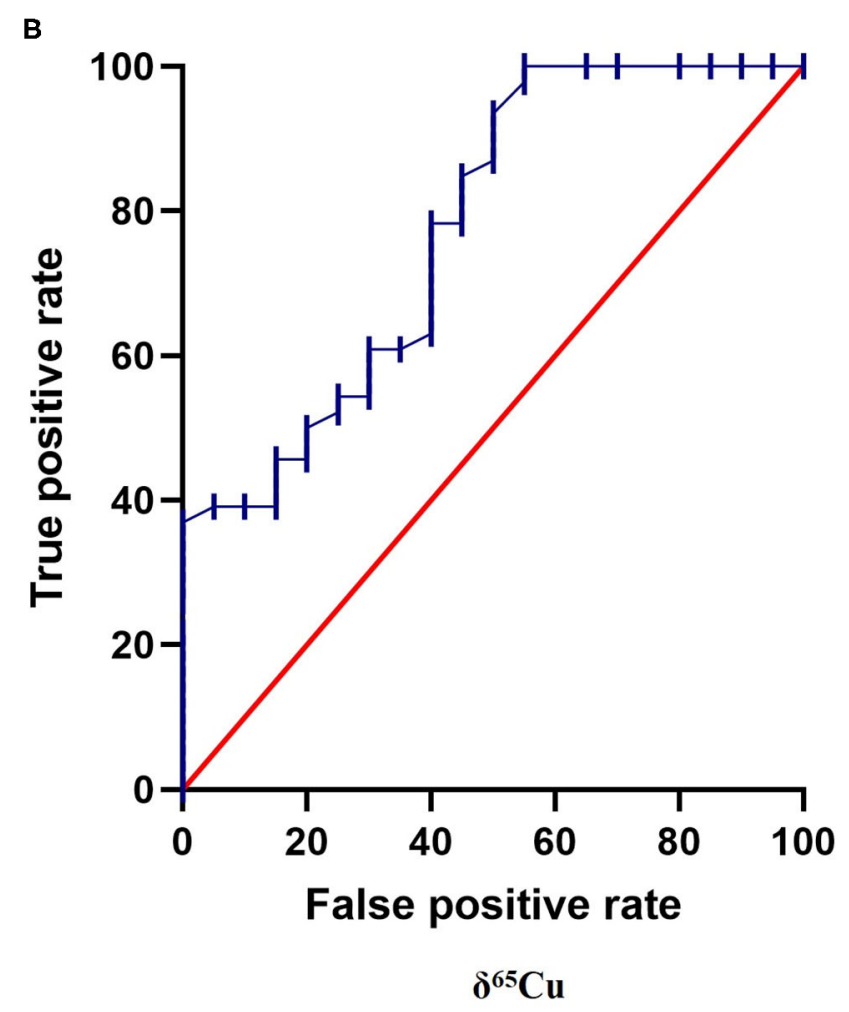

FIGURE 4 | Receiver Operating Characteristics (ROC) curve for: (A) Cu/Zn Ratio and (B) $\delta^{65} \mathrm{Cu}$ in the plasma of papillary thyroid carcinoma. We place the True Positive decision on the ordinate axis and False Positive rate on the abscissa to form the ROC diagram. The area under the ROC curve (AUC) obtained for the present data were 0.81 and 0.78 , respectively $(p<0.001)$ supports the hypothesis that $\mathrm{Cu} / \mathrm{Zn}$ ratio and $\delta^{65} \mathrm{Cu}$ have a strong potential to be a novels biomarker in diagnosis for thyroid cancer.

In addition, during the inflammatory response, $\mathrm{Cu}$ is mobilized and accumulates in inflamed tissues, contributing to the defense against various infections. However, chronic inflammation is a risk factor in the development of cancer. Certain inflammatory cytokines, such as IL-6 and IL-17, are diagnostic markers for early phase of inflammation and they interact in the promotion of tumors and cancer progression and they act in the regulation of $\mathrm{Cu}$ uptake mechanisms, thus contributing to the accumulation of $\mathrm{Cu}$ in cancer cells $(24,43)$.

Secondly, Zinc is a micronutrient required for the biosynthesis of thyroid hormones, and $\mathrm{Zn}$ affects the activity of $5^{\prime}$-deiodinase for the conversion of T4 to triiodothyronine (T3) $(44,45)$. In addition, $\mathrm{Zn}$ is necessary for the synthesis of TSH from pituitary and TRH from hypothalamus $(46,47)$. Kralik et al. (48) showed $\mathrm{Zn}$ to be required for the correct metabolism of thyroid hormone, and $\mathrm{Zn}$ deficiency might have a negative effect on the activity of normal thyroid. Meta-analysis conducted by Gumulec et al. (49) provided evidence for Zn level to alter cancer-specific tissue, with low $\mathrm{Zn}$ concentration associated with most tumors and in particular with thyroid carcinoma.

Few studies reported a lower levels of $\mathrm{Zn}$ and relatively higher levels of $\mathrm{Cu}$ in thyroid cancer patients (46). The study of Lin et al. (50) found significantly lower concentration of $\mathrm{Zn}$ (0.73 vs. $1.01 \mathrm{mg} / \mathrm{L})$ with significantly higher levels of $\mathrm{Cu}(1.16 \mathrm{mg} / \mathrm{L}$ vs.
$0.92 \mathrm{mg} / \mathrm{L}$ ) in patients with hepatocellular carcinoma compared to controls. Baltaci et al. (46) found a negative correlation between lower levels of $\mathrm{Zn}$ and higher levels of $\mathrm{Cu}$ in the same patients. There is an antagonistic relationship between $\mathrm{Cu}$ and $\mathrm{Zn}$; a diet rich in zinc (overdose) may lead to disruption of $\mathrm{Cu}$ absorption, and conversely a high dose of $\mathrm{Cu}$ may decrease $\mathrm{Zn}$ absorption $(51,52)$. This could explain the results obtained in our patients showing a perturbation in their $\mathrm{Cu} / \mathrm{Zn}$ ratio. Alternatively, the altered $\mathrm{Cu} / \mathrm{Zn}$ ratio may reflect the ongoing inflammation during thyroid cancer, which may set in early. In general, $\mathrm{Cu}$ is upregulated as positive acute phase reactant, whereas $\mathrm{Zn}$ tends to decline in response to inflammation. This inverse response to cytokines may contribute and synergize with the antagonistic changes of trace element absorption mentioned above.

Furthermore, during the synthesis of thyroid hormones, free radicals (ROS) are produced (53). It has been reported that SOD enzymes are involved in the thyroid gland functioning (54). Through cellular protection mechanisms, SOD enzymes eliminate excess ROS and prevent tumor progression through cellular protection mechanisms. On the other hand, the disturbance of the $\mathrm{Cu}-\mathrm{Zn}$ homeostasis and an overproduction of ROS can lead to DNA damage, protein modification and eventually to the development of cancer (10). This may also 
explain the $\mathrm{Cu} / \mathrm{Zn}$ imbalance observed in our thyroid cancer patient cohorts.

We found higher $\mathrm{Cu} / \mathrm{Zn}$ ratio in PTC patients compared to healthy controls, this result was similar to previous studies conducted on breast, prostate, colorectal, and uterine cervical cancer $(55,56)$. The $\mathrm{Cu} / \mathrm{Zn}$ ratio is considered as a potential biomarker for cancer detection (24). Our results support its potential value for PTC detection, thereby expanding its potential use as screening and diagnosis tool to the thyroid gland.

Some studies reported the influence of thyroid hormones in $\mathrm{Cu}$ and $\mathrm{Zn}$ metabolism $(36,57)$. It was observed that thyroid hormones can influence the expression of $\mathrm{Cu}$ transport proteins (ATP7A and ATP7B) and regulate serum Cu levels by controlling the production of the $\mathrm{Cu}$-transport protein ceruloplasmin (58). In addition, it was found a significant correlation between TSH and $\mathrm{Zn}$ levels in hyperthyroidism (59). However, in our study we found no significant association between trace metals and thyroid parameters.

\section{Copper Isotopic Composition}

With the development of new sensitive techniques such as MC-ICP-MS a search for non-invasive low-cost biomarkers has emerged, aiming at the development of early disease diagnosis. In this study, the $\delta^{65} \mathrm{Cu}$ marker is used and based on the determination of two stable $\mathrm{Cu}$ isotopes concentration ratio $\left({ }^{65} \mathrm{Cu} /{ }^{63} \mathrm{Cu}\right)$. We evaluated the $\mathrm{Cu}$ fractionation in blood and in tissues samples of patients with PTC and found significantly lower plasma value of $\delta^{65} \mathrm{Cu}$ in patients with PTC compared to healthy controls, and in a mirror image, significant higher values of $\delta^{65} \mathrm{Cu}$ in thyroid tumor tissue. Studies conducted in breast, colorectal and ovarian cancer found similar results, and have shown lighter enrichment in ${ }^{63} \mathrm{Cu}$ isotope in serum and heavier enrichment in the ${ }^{65} \mathrm{Cu}$ isotope in tissue, due to a preferential uptake of the heavy isotope by tumor cells $(12,21)$.

We used ROC curve analysis (Figure 4B) to evaluate the use of $\mathrm{Cu}$ isotope as diagnostic biomarker for thyroid cancer. The ROC curve is a widely used tool in diagnostic medicine. It represents the ability of a test to discriminate between the patient and non-patient population (60). The ROC curve represents on the ordinate the proportion of positive tests among the patient's population (the sensitivity), in our case the $\delta^{65} \mathrm{Cu}$ values of the thyroid cancer patients, vs. the proportion of positive tests among the non-diseased population. The reliability of the results is assessed by the AUC which ranges from 0.5 (pure chance) to 1.0 (totally reliable test). The ROC curve represents all the points calculated for each $\delta^{65} \mathrm{Cu}$ sample value. In the present case of thyroid cancer diagnosis, the AUC is equal to 0.78 and were similar to that observed in breast cancer (12). The use of ${ }^{65} \mathrm{Cu}$ as a potential diagnostic tool for thyroid cancer seems very promising.

The isotopic variability can be influenced by different mechanisms such menopause $(61,62)$ or biological sex $(20)$. ${ }^{65} \mathrm{Cu}$ values seem also to vary according to diet. In fact, Jaouen et al. (20) demonstrated that $\mathrm{Cu}$ isotope composition of healthy Yakut's serum are significantly different (lighter) than observed in reference panel of Japanese and European population and supposed to be related to the isotope composition of the diet.
The isotopic fractionation in diet can be generated during the intestinal absorption or excretion of food inducing differences in the isotopic composition of the human body or reflect different biogeochemical origins of the food items. Furthermore, it has been observed that metabolic reactions can also cause isotopic fractionation. In several diseases, such as cancer, this metabolic change can be measured (63).

As previously highlighted, the cause of isotopic fractionation in the case of cancer is not well understood but it has been suggested by Telouk et al. (12), that the hypoxic environment in tumor cells would be at the origin of the decrease of $\delta^{65} \mathrm{Cu}$ in the serum and the enrichment of $\delta^{65} \mathrm{Cu}$ in the tissues. It has been reported that in solid tumors there is a preferential chelation of the heavy ${ }^{65} \mathrm{Cu}$ isotope in the tumor tissues and the release of the light ${ }^{63} \mathrm{Cu}$ isotope into the blood $(12,19)$. However, some studies on hematological cancer found different $\delta^{65} \mathrm{Cu}$ values in tumor patients vs. controls, but at the same time similar isotopic fractionation in plasma and solid tumors, suggesting that the mechanism responsible for this distribution was not related to preferential absorption and release from the tumor but was caused by the proliferation of tumor cells (23). The mechanism of isotopic fractionation is thus not yet fully understood, and further studies in cellular and subcellular range are needed to elucidate this variation.

\section{CONCLUSION}

The assessment of $\mathrm{Cu}$ and $\mathrm{Zn}$ plasma levels showed higher $\mathrm{Cu}$ and lower $\mathrm{Zn}$ concentrations in PTC patients compared to healthy controls, yielding a highly significant difference in the plasma $\mathrm{Cu} / \mathrm{Zn}$ ratio. In addition, the $\mathrm{Cu}$ isotopic composition was strongly different in the thyroid cancer, patients as compared to healthy controls. Notably, the ${ }^{65} \mathrm{Cu}$ values differed in opposite directions in plasma vs. the thyroid tumor tissue samples. Our study supports the hypothesis that trace element concentrations and isotopic composition have a high potential to be used as additional biomarkers in the detection of thyroid cancer. Further molecular studies are needed for a better comprehension of the mechanisms involved in these processes.

\section{DATA AVAILABILITY STATEMENT}

The original contributions presented in the study are included in the article, further inquiries can be directed to the corresponding author/s.

\section{ETHICS STATEMENT}

The studies involving human participants were reviewed and approved by Scientific Ethics Deontology Committee of Tlemcen University. The patients/participants provided their written informed consent to participate in this study.

\section{AUTHOR CONTRIBUTIONS}

AG, LK, LC, and ND-M designed the study. MB, LK, and MD-S collected the sample and data via face-to-face interviews. 
LK, AG, and PT performed copper isotope assessment. LS, $\mathrm{QS}$, and $\mathrm{JH}$ did the $\mathrm{Cu}$ and $\mathrm{Zn}$ measurements. $\mathrm{LK}$ and $\mathrm{YH}$ performed the statistical analyses. LK, AG, and ND-M prepared the manuscript. LC and LS corrected the final version. All authors have read and agreed to the published version of the manuscript.

\section{FUNDING}

This study benefited from the financial support from ISTerre and the inter-Instituts of CNRS. Deutsche Forschungsgemeinschaft

\section{REFERENCES}

1. Curado MP, Edwards B, Shin HR, Storm H, Ferlay J, Heanue M, et al. Cancer incidence in Five Continents Volume IX. Lyon: International Agency for Research on Cancer (2008). p. 837.

2. Castro B, Rodrigues E. Molecular biology of papillary thyroid microcarcinomas: what is new? Endocrinol Diabetes E Metab. (2016) 11:287-95. doi: 10.1016/j.rpedm.2016.04.003

3. Thyroid Cancer. Cancer Stat Facts. (2020). Available online at: https://seer. cancer.gov/statfacts/html/thyro.html.

4. Barrea L, Gallo M, Ruggeri RM, Giacinto PD, Sesti F, Prinzi N, et al. Nutritional status and follicular-derived thyroid cancer: an update. Crit Rev Food Sci Nutr. (2021) 61:25-59. doi: 10.1080/10408398.2020.1714542

5. International Agency for Research on Cancer. GLOBO-CAN 2018: Estimated Cancer Incidence, Mortality and Prevalence in Algeria in 2018. IARC (2019). Available online at: http://globocan.iarc.fr/.

6. Benouis A, Bekkouche Z, Merad MS, Loudjedi L, Khelil H, Berber N. Thyroid cancer in Western Algeria: histopathological and epidemiological study. $J$ Cancer Ther. (2017) 08:672-82. doi: 10.4236/jct.2017.87058

7. Cabanillas ME, McFadden DG, Durante C. Thyroid cancer. Lancet. (2016) 388:2783-95. doi: 10.1016/S0140-6736(16)30172-6

8. Kaliszewski K, Diakowska D, Wojtczak B, Rudnicki J. Cancer screening activity results in overdiagnosis and overtreatment of papillary thyroid cancer: a 10-year experience at a single institution. PLOS ONE. (2020) 15:e0236257. doi: 10.1371/journal.pone.0236257

9. Linder M. Biochemistry of Copper. New York, NY: Springer Science Business Media. (2013). p. 526

10. Ishida S, Andreux P, Poitry-Yamate C, Auwerx J, Hanahan D. Bioavailable copper modulates oxidative phosphorylation and growth of tumors. Proc Natl Acad Sci USA. (2013) 110:19507-12. doi: 10.1073/pnas.1318431110

11. Ishida S, McCormick F, Smith-McCune K, Hanahan D. Enhancing tumorspecific uptake of the anticancer drug cisplatin with a copper chelator. Cancer Cell. (2010) 17:574-83. doi: 10.1016/j.ccr.2010.04.011

12. Télouk P, Puisieux A, Fujii T, Balter V, Bondanese VP, Morel A-P, et al. Copper isotope effect in serum of cancer patients. A pilot study. Metallomics. (2015) 7:299-308. doi: 10.1039/C4MT00269E

13. Osredkar J, Susta N. Copper and zinc, biological role and significance of copper/zinc imbalance. J Clin Toxicol. (2011) S3:001. doi: 10.4172/2161-0495.S3-001

14. Asaduzzaman K M, Tania M, Zhang D, Chen H. Antioxidant enzymes and cancer. Chin J Cancer Res. (2010) 22:87-92. doi: 10.1007/s11670-010-0087-7

15. Somwar R, Erdjument-Bromage H, Larsson E, Shum D, Lockwood WW, Yang G, et al. Superoxide dismutase 1 (SOD1) is a target for a small molecule identified in a screen for inhibitors of the growth of lung adenocarcinoma cell lines. Proc Natl Acad Sci USA. (2011) 108:1637580. doi: 10.1073/pnas.1113554108

16. Yücel I, Arpaci F, Özet A, Döner B, Karayilanoglu T, Sayar A, et al. Serum copper and zinc levels and Copper/Zinc ratio in patients with breast cancer. Biol Trace Elem Res. (1994) 40:31-8. doi: 10.1007/BF029 16818

17. Cui Y, Vogt S, Olson N, Glass AG, Rohan TE. Levels of zinc, selenium, calcium, and iron in benign breast tissue and risk of
(DFG), Research Unit FOR-2558 (Scho 849/6-2) and CRC/TR 296 (LocoTact, P17) to LS.

\section{ACKNOWLEDGMENTS}

This study was performed using the INSU/CNRS MC-ICPMS national facility at ENS-LYON. We also thank a Profas $\mathrm{B}+$ algero-french ministerial scholarship awarded to LK, which made possible an active collaboration between University of Grenoble Alpes, France and University Abou Bekr Belkaid, Tlemcen, Algeria.

subsequent breast cancer. Cancer Epidemiol Biomarkers Prev. (2007) 16:1682-5. doi: 10.1158/1055-9965.EPI-07-0187

18. Bertinato J. Copper: physiology. In: Encyclopedia of Food and Health. Ottawa, ON: Elsevier. (2016). p. 321-6.

19. Balter V, Nogueira da Costa A, Bondanese VP, Jaouen K, Lamboux A, Sangrajrang S, et al. Natural variations of copper and sulfur stable isotopes in blood of hepatocellular carcinoma patients. Proc Natl Acad Sci USA. (2015) 112:982-5. doi: 10.1073/pnas.1415151112

20. Jaouen K, Gibert M, Lamboux A, Telouk P, Fourel F, Albarède F, et al. Is aging recorded in blood $\mathrm{Cu}$ and $\mathrm{Zn}$ isotope compositions? Metallomics. (2013) 5:1016-24. doi: 10.1039/C3MT00085K

21. Toubhans B, Gourlan AT, Telouk P, Lutchman-Singh K, Francis LW, Conlan $\mathrm{RS}$, et al. $\mathrm{Cu}$ isotope ratios are meaningful in ovarian cancer diagnosis. J Trace Elem Med Biol. (2020) 62:126611. doi: 10.1016/j.jtemb.2020.126611

22. Bondanese VP, Lamboux A, Simon M, Lafont JE, Albalat E, Pichat S, et al. Hypoxia induces copper stable isotope fractionation in hepatocellular carcinoma, in a HIF-independent manner. Metallomics. (2016) 8:117784. doi: 10.1039/C6MT00102E

23. Hastuti AAMB, Costas-Rodríguez M, Matsunaga A, Ichinose T, Hagiwara $\mathrm{S}$, Shimura $\mathrm{M}$, et al. $\mathrm{Cu}$ and $\mathrm{Zn}$ isotope ratio variations in plasma for survival prediction in hematological malignancy cases. Sci Rep. (2020) 10:16389. doi: 10.1038/s41598-020-71764-7

24. Wisniewska M, Cremer M, Wiehe L, Becker N-P, Rijntjes E, Martitz J, et al. Copper to Zinc ratio as disease biomarker in neonates with early-onset congenital infections. Nutrients. (2017) 9:343. doi: 10.3390/nu9040343

25. Stepien M, Hughes DJ, Hybsier S, Bamia C, Tjønneland A, Overvad K, et al. Circulating copper and Zinc levels and risk of hepatobiliary cancers in Europeans. Br J Cancer. (2017) 116:688-96. doi: 10.1038/bjc.2017.1

26. Albarède F, Telouk P, Lamboux A, Jaouen K, Balter V. Isotopic evidence of unaccounted for $\mathrm{Fe}$ and $\mathrm{Cu}$ erythropoietic pathways. Metallomics. (2011) 3:926. doi: 10.1039/c1mt00025j

27. Maréchal $\mathrm{CN}$, Télouk $\mathrm{P}$, Albarède F. Precise analysis of copper and zinc isotopic compositions by plasma-source mass spectrometry. Chem Geol. (1999) 156:251-73. doi: 10.1016/S0009-2541(98)00191-0

28. Mehl S, Sun Q, Görlich CL, Hackler J, Kopp JF, Renko K, et al. Cross-sectional analysis of trace element status in thyroid disease. J Trace Elem Med Biol. (2020) 58:126430. doi: 10.1016/j.jtemb.2019.126430

29. Heitland P, Köster HD. Biomonitoring of 37 trace elements in blood samples from inhabitants of northern Germany by ICP-MS. J Trace Elem Med Biol. (2006) 20:253-62. doi: 10.1016/j.jtemb.2006.08.001

30. Gammoh N, Rink L. Zinc in infection and inflammation. Nutrients. (2017) 9:624. doi: 10.3390/nu9060624

31. Rezaei M, Javadmoosavi SY, Mansouri B, Azadi NA, Mehrpour O, Nakhaee S. Thyroid dysfunction: how concentration of toxic and essential elements contribute to risk of hypothyroidism, hyperthyroidism, and thyroid cancer. Environ Sci Pollut Res. (2019) 26:35787-96. doi: 10.1007/s11356-019-06632-7

32. Liu Y, Liu S, Mao J, Piao S, Qin J, Peng S, et al. Serum trace elements profile in graves' disease patients with or without orbitopathy in Northeast China. BioMed Res Int. (2018) 2018:1-8. doi: 10.1155/2018/3029379

33. Kazi TG, Kandhro GA, Afridi HI, Kazi N, Baig JA, Arain MB, et al. Interaction of copper with iron, iodine, and thyroid hormone status in goitrous patients. Biol Trace Elem Res. (2010) 134:265-79. doi: 10.1007/s12011-009-8478-7 
34. Shen F, Cai W-S, Li J-L, Feng Z, Cao J, Xu B. The association between serum levels of selenium, copper, and magnesium with thyroid cancer: a meta-analysis. Biol Trace Elem Res. (2015) 167:225-35. doi: 10.1007/s12011-015-0304-9

35. Giray B, Arnaud J, Sayek I, Favier A, Hincal F. Trace elements status in multinodular goiter. J Trace Elem Med Biol. (2010) 24:10610. doi: 10.1016/j.jtemb.2009.11.003

36. Hybsier S, Höfig C, Mittag J, Brabant G, Schomburg L. Control of serum copper $(\mathrm{Cu})$ and selenium (Se) status by thyroid hormones. Exp Clin Endocrinol Diabetes. (2015) 122:s-00351547752. doi: 10.1055/s-0035-1547752

37. Linder MC, Moor JR, Wright K. Ceruloplasmin assays in diagnosis and treatment of human lung, breast, and gastrointestinal cancers. J Natl Cancer Inst. (1981) 67:263-75.

38. Theophanides T, Anastassopoulou J. Copper and carcinogenesis. Crit Rev Oncol Hematol. (2002) 42:57-64. doi: 10.1016/S1040-8428(02)00007-0

39. Brem N. Angiogenesis and Cancer Control: From Concept to Therapeutic Trial. Cancer Control J Moffitt Cancer Cent. (1999) 6:436-58. doi: 10.1177/107327489900600502

40. Brem SS, Zagzag D, Tsanaclis AM, Gately S, Elkouby MP, Brien SE. Inhibition of angiogenesis and tumor growth in the brain. Suppression of endothelial cell turnover by penicillamine and the depletion of copper, an angiogenic cofactor. Am J Pathol. (1990) 137:1121-42.

41. Skrajnowska D, Bobrowska-Korczak B, Tokarz A, Bialek S, Jezierska E, Makowska J. Copper and resveratrol attenuates serum catalase, glutathione peroxidase, and element values in rats with DMBAinduced mammary carcinogenesis. Biol Trace Elem Res. (2013) 156:271-8. doi: 10.1007/s12011-013-9854-x

42. Denoyer D, Masaldan S, La Fontaine S, Cater MA. Targeting copper in cancer therapy: "Copper That Cancer". Metallomics. (2015) 7:145976. doi: 10.1039/C5MT00149H

43. Liao Y, Zhao J, Bulek K, Tang F, Chen X, Cai G, et al. Inflammation mobilizes copper metabolism to promote colon tumorigenesis via an IL-17-STEAP4XIAP axis. Nat Commun. (2020) 11:900. doi: 10.1038/s41467-020-14698-y

44. Barnett JB, Dao MC, Hamer DH, Kandel R, Brandeis G, Wu D, et al. Effect of zinc supplementation on serum zinc concentration and $\mathrm{T}$ cell proliferation in nursing home elderly: a randomized, double-blind, placebocontrolled trial. Am J Clin Nutr. (2016) 103:942-51. doi: 10.3945/ajcn.115.1 15188

45. Danforth E, Burger AG. The Impact of Nutrition on Thyroid Hormone Physiology and Action. Annu Rev Nutr. (1989) 9:201-27. doi: 10.1146/annurev.nu.09.070189.001221

46. Baltaci AK, Dundar TK, Aksoy F, Mogulkoc R. Changes in the serum levels of trace elements before and after the operation in thyroid cancer patients. Biol Trace Elem Res. (2017) 175:57-64. doi: 10.1007/s12011-0160768-2

47. Suzuki S, Kasai K, Yamauchi K. Characterization of little skate (Leucoraja erinacea) recombinant transthyretin: Zinc-dependent 3, 3',5-triiodo-1-thyronine binding. Gen Comp Endocrinol. (2015) 217-218:43-53. doi: 10.1016/j.ygcen.2015.04.006

48. Kralik A, Eder K, Kirchgessner M. Influence of Zinc and Selenium Deficiency on Parameters Relating to Thyroid Hormone Metabolism. Horm Metab Res. (1996) 28:223-6. doi: 10.1055/s-2007-979169

49. Gumulec J, Masarik M, Adam V, Eckschlager T, Provaznik I, Kizek R. Serum and tissue Zinc in epithelial malignancies: a meta-analysis. PLoS ONE. (2014) 9:e99790. doi: 10.1371/journal.pone.0099790

50. Lin CC, Huang JF, Tsai LY, Huang YL. Selenium, iron, copper, and zinc levels and copper-to-zinc ratios in serum of patients at different stages of viral hepatic diseases. Biol Trace Elem Res. (2006) 109:01524. doi: 10.1385/BTER:109:1:015
51. Kaslow JE. Copper/Zinc Imbalance. California: Medical Board of California. (2011).

52. Balay KS, Hawthorne KM, Hicks PD, Chen Z, Griffin IJ, Abrams SA. Low Zinc Status and Absorption Exist in Infants with Jejunostomies or Ileostomies Which Persists after Intestinal Repair. Nutrients. (2012) 4:127381. doi: 10.3390/nu4091273

53. Sugawara M. Reactive Oxygen Species and Thyroid Diseases. Sys Biol of Free Rad and Anti. (2014) 3521-38. doi: 10.1007/978-3-642-30018-9_150

54. Iwase $\mathrm{K}$, Nagasaka $\mathrm{A}$, Kato $\mathrm{K}$, Ohtani $\mathrm{S}$, Tsujimura $\mathrm{T}$, Inagaki $\mathrm{A}$, et al. Localization of $\mathrm{Cu} / \mathrm{Zn}$ and $\mathrm{Mn}$ superoxide dismutase in various thyroid disorders. Acta Endocrinol (Copenh). (1993) 129:573-8. doi: 10.1530/acta.0.1290573

55. Adaramoye OA, Akinloye O, Olatunji IK. Trace elements and vitamin E status in Nigerian patients with prostate cancer. Afr Health Sci. (2010) 10:2-8.

56. Cunzhi H, Jiexian J, Xianwen Z, Jingang G, Shumin Z, Lili D. Serum and tissue levels of six trace elements and Copper/Zinc ratio in patients with cervical cancer and uterine myoma. Biol Trace Elem Res. (2003) 94:11322. doi: 10.1385/BTER:94:2:113

57. Hanif S, Ilyas A, Shah MH. Statistical evaluation of trace metals, TSH and T4 in blood serum of thyroid disease patients in comparison with controls. Biol Trace Elem Res. (2018) 183:58-70. doi: 10.1007/s12011-017-1137-5

58. Mittag J, Behrends T, Nordström K, Anselmo J, Vennström B, Schomburg L. Serum copper as a novel biomarker for resistance to thyroid hormone. Biochem J. (2012) 443:103-9. doi: 10.1042/BJ20111817

59. Sinha S, Kar K, Dasgupta A, Basu S, Sen S. Correlation of Serum zinc with TSH in hyperthyroidism. Asian J Med Sci. (2015) 7:669. doi: 10.3126/ajms.v7i1.12895

60. Delacour H, Servonnet A, Perrot A, Vigezzi JF, Ramirez JM. La courbe ROC (receiver operating characteristic): principes et principales applications en biologie clinique. Ann Biol Clin. (2005) 63:10.

61. Van Heghe L, Deltombe O, Delanghe J, Depypere H, Vanhaecke F. The influence of menstrual blood loss and age on the isotopic composition of $\mathrm{Cu}, \mathrm{Fe}$ and $\mathrm{Zn}$ in human whole blood. J Anal Spectrom. (2014) 29:47882. doi: 10.1039/C3JA50269D

62. Jaouen $\mathrm{K}$, Balter V. Menopause effect on blood $\mathrm{Fe}$ and $\mathrm{Cu}$ isotope compositions: menopause effect on blood $\mathrm{Fe}$ and $\mathrm{Cu}$ isotopes. Am J Phys Anthropol. (2014) 153:280-5. doi: 10.1002/ajpa.22430

63. Jaouen K, Pons M-L. Potential of non-traditional isotope studies for bioarchaeology. Archaeol Anthropol Sci. (2017) 9:1389-404. doi: 10.1007/s12520-016-0426-9

Conflict of Interest: The authors declare that the research was conducted in the absence of any commercial or financial relationships that could be construed as a potential conflict of interest.

Publisher's Note: All claims expressed in this article are solely those of the authors and do not necessarily represent those of their affiliated organizations, or those of the publisher, the editors and the reviewers. Any product that may be evaluated in this article, or claim that may be made by its manufacturer, is not guaranteed or endorsed by the publisher.

Copyright (c) 2021 Kazi Tani, Gourlan, Dennouni-Medjati, Telouk, Dali-Sahi, Harek, Sun, Hackler, Belhadj, Schomburg and Charlet. This is an open-access article distributed under the terms of the Creative Commons Attribution License (CC BY). The use, distribution or reproduction in other forums is permitted, provided the original author(s) and the copyright owner(s) are credited and that the original publication in this journal is cited, in accordance with accepted academic practice. No use, distribution or reproduction is permitted which does not comply with these terms. 